\title{
Dangerous Days: The Impact of Nationalism on Interstate Conflict
}

Does an upsurge in nationalism make interstate conflict more likely? This article gives evidence to suggest that spikes in nationalism do have a direct impact on the likelihood of disputes between states. In it I use national days or anniversaries as occasions that increase the salience of the national identity and its historical wars. I show that in the two months following national days, conflict is markedly higher than would be expected; almost $30 \%$ more likely than the rest of the year; and particularly for states who initiate conflict or who have revisionist intentions. I demonstrate further how nationalist sentiment can increase international tensions with a case study of national anniversaries in China and Japan. Together this evidence suggests that the increase in nationalism around national days provides both risks and opportunities to regimes, and shapes when they choose conflict over cooperation in international relations.

Author: Jamie Gruffydd-Jones 
On the $3^{\text {rd }}$ of September 2015 the Chinese Communist Party (CCP) launched a nationwide celebration of the $70^{\text {th }}$ anniversary of the end of the Second World War. For the victory parade the CCP closed the streets of Beijing ${ }^{1}$, announced a public holiday and invited world leaders to Beijing for the party ${ }^{2}$. In addition to the parade of twelve thousand troops and sparkling new military equipment, the Chinese government launched a hefty propaganda campaign commemorating the war ${ }^{3}$, cleaned up Beijing's air ${ }^{4}$ and pardoned jailed war veterans ${ }^{5}$. General Secretary Xi Jinping focused his speech on Japan, saying that the "great triumph crushed the plot of the Japanese militarists to colonize and enslave China"6. A Japanese spokesman in response called Xi's speech 'anti-Japanese'7, echoing commentators' warnings that Beijing's naked display of nationalism risked sparking tensions in an already hostile East Asian environment ${ }^{8}$.

But what is the true impact on international relations of this kind of nationalist spectacle; the kind that rouses flag-waving citizens onto the streets and revives memories of conflicts with old enemies? And what can they tell us about the impact of nationalism on the likelihood of war? International relations scholars have long portrayed people's attachment to their nation as one of the most potent forces behind a state's decision to go to war', yet few have clearly demonstrated that it has a genuine

\footnotetext{
1 "Roads Closed, Monkeys on Patrol Ahead of WWII Parade". China Digital Times, September 2, 2015

2 "The attendees to China's military parade: leaders of the world's least-powerful countries". Quartz, August 25, 2015

3 “Minitrue: Don’t Rain On Our Military Parade”. China Digital Times, August 24, 2015

4 “Beijing Smog Gives Way to 'Military Parade Blue' Before World War II Event”. New York Times, August 25, 2015

${ }^{5}$ China grants amnesty to mark anniversary of WW2 victory. Reuters, August 29, 2015

6 "Beijing: Xi Jinping Slams Japanese Aggression in Military Parade Speech". The Diplomat, September 3, 2015

7 "Japan 'disappointed' by Chinese leader's WWII speech". Channel News Asia, September 3, 2015

8 "Militarism is a Risky Temptation for Beijing". Financial Times, August 31, 2015. "China stresses nationalism in war anniversary propaganda push". Reuters, July 6, 2015

${ }^{9}$ Summarised well in Stephen Van Evera, "Hypotheses on Nationalism and War." International Security 18, No.4 (1994): 5-39
} 
impact on how and when conflict occurs. Attempts to give evidence for this story have struggled to escape the problem that government attempts to rally their population to support wars may be the very things that cause nationalism to rise. Annual national celebrations provide one plausible means of testing whether increases in nationalism do in fact affect the patterns of conflict between countries.

This study tests the proposition that, as proxies for an increase in nationalism, national days lead to an increase in interstate conflict. I first examine the literature on nationalism before showing that these occasions bring opportunities and risks for leaders, which may lead to international tensions and even conflict. I argue that regimes can exploit the public national feeling around the days to support their assertive acts overseas; but that nationalist groups may also exploit this feeling to push regimes into unwanted confrontations. National days give leaders, every year, a choice over whether they should exploit or resist public nationalism, a choice which overall makes conflict more likely in the subsequent weeks and months. I test this argument by examining whether, between 1991 and 2010, states' Militarized Interstate Disputes are more prevalent in the period following their main national day or anniversary. I show that conflicts are significantly more likely to begin in the two months following a national day than the rest of the year, and that this holds more strongly for the state that begins the dispute, and for the one looking to change the status quo. Finally I illustrate the mechanisms involved with a case study of war anniversaries between China and Japan over the last twenty years.

\section{The Impact of Nationalism on Conflict}


Nationalism, according to Haas, is an ideology that makes "assertions about the nation's claim to historical uniqueness, to the territory that the nation-state ought to occupy, and to the kinds of relations that should prevail between one's nation and others" ${ }^{10}$. In International Relations scholarship, this ideology is one of the most dependable culprits for conflict between nations ${ }^{11}$, yet to date few scholars have isolated the variable and directly examined its impact on international behavior.

Schrock-Jacobsen tests this explicitly. She shows that the greater amount of nationalist rhetoric a country's leaders use in a given year, the more likely it will go to war the following year ${ }^{12}$. The problem, however, is of endogeneity; nationalist rhetoric may have increased precisely because tensions with international opponents were already growing. The strength of national sentiment is likely to be dependent on the build up to the conflict itself, as members of the public respond to international tensions and attempts by their leaders to rally the population for war. As such, most attempts to measure the impact of increases in national sentiment by examining it directly will struggle to parcel out whether it has caused the build-up to a conflict or have been caused by that same build up. Given this problem, how can we show that waves of public nationalism or leaders' nationalist rhetoric do have an impact on international conflict?

\footnotetext{
${ }^{10}$ Ernst B. Haas, "What is nationalism and why should we study it?" International Organization 40, no.3 (1986): 727

${ }^{11}$ Van Evera (1994); Valere P. Gagnon "Ethnic Nationalism and International Conflict", International Security 19 No. 3 (1994), 130-166; Barry R. Posen, "Nationalism, the Mass Army and Military Power", International Security 18, No. 2 (1993), 80-124

${ }^{12}$ Gretchen Schrock-Jacobson, "The Violent Consequences of the Nation: Nationalism and the Initiation of Interstate War." Journal of Conflict Resolution 56, no.5 (2012): 825-852
} 
One way is to examine the occasions when there is an increase in nationalism independent of international tensions or the build-up to war ${ }^{13}$. Mansfield and Snyder's account is one of the few studies to succeed here, showing that appeals to nationalism become more prevalent at times when legitimacy is particularly important- around elections- and that at these times in democratizing regimes (where the appeals exert their greatest influence), interstate conflict becomes more likely ${ }^{14}$. Persuasive though the argument is, some have argued these findings do not hold using different case selection and statistical methods ${ }^{15}$, and it is not necessarily nationalism that is doing the main work: there are many developments around elections in democratizing regimes, including interparty violence and uncertain leadership transitions, all which may have impacts on conflict.

An example more intuitively related to nationalism is sporting events. Andrew Bertoli tests the impact of attendance at the football World Cup on conflict behavior. He shows that those countries that narrowly gained qualification were substantially more likely to see interstate conflict at the time of the World Cup than those that narrowly missed out ${ }^{16}$. Sporting occasions are plausible outlets for nationalist sentiment, but the routes through which they might lead to conflict may not be generalizable. The most obvious path, as Bertoli notes, is where fights between fans placed in direct opposition to each other escalate to riots and then diplomatic fallout ${ }^{17}$ - an event that is hard to extend to non-sporting occasions.

\footnotetext{
${ }^{13}$ Gary King, Robert O. Keohane, and Sidney Verba, Designing social inquiry: Scientific inference in qualitative research. PUP, (1994)

${ }^{14}$ Edward D. Mansfield and Jack Snyder, "Democratization and the Danger of War." International security 20, no. 1 (1995): 5-38

${ }^{15}$ Andrew J. Enterline, “Correspondence on 'Driving While Democratizing'," International Security 20 (1996): 183-196; and William R. Thompson and Richard M. Tucker, "A Tale of Two Democratic Peace Critiques.” Journal of Conflict Resolution 41 (1997): 428-451

${ }^{16}$ Andrew Bertoli, "Nationalism and Interstate Conflict: A Regression Discontinuity Analysis." In APSA 2013 Annual Meeting Paper. 2013

${ }^{17}$ Bertoli (2013)
} 
Even more closely linked to increases in nationalism are national days. National days and prominent anniversaries of independence or war celebrate not only the nation but in many cases also its victory (or loss) against other nations ${ }^{18}$. In this article I refer to national days not just as the official public-holiday 'National Days' celebrated in many countries, but any "days in which the 'national' is paraded and consumed"19. They generally occur on the same date every year, irrespective of whether a country is in the build up to a conflict, and as McCrone and McPherson note, are times in which you "can't escape unless you leave the country or stay indoors" 20 . As public displays of the national identity, they provide an unexplored means of measuring regular, countrywide increases in nationalism. The pattern of media celebration, flag waving, and marches also reflects a more common way by which nationalism is normally expressed than the intense fan-based fervor of sporting events. When national days are anniversaries of wars or independence, they are often militarized, with public memorials of past conflict and parades of arms.

While the anthropological and sociological literature has discussed why states celebrate national days and anniversaries ${ }^{21}$, there is little systematic examination of their effects, either on society or state. Blake examines cultural marches, a key part of many anniversary celebrations. While he argues that Orange Order marches in Northern Ireland serve to draw a wedge between communities, he focuses his analysis

\footnotetext{
${ }^{18}$ Gabriella Elgenius, "The politics of recognition: symbols, nation building and rival nationalisms." Nations and Nationalism 17, no.2 (2011): 396-418

${ }^{19}$ David McCrone and Gayle McPherson, eds. National Days: Constructing and Mobilizing National Identity. Palgrave Macmillan, 2009: 3

${ }^{20}$ McCrone and McPherson (2009): 2

${ }^{21}$ For example: Wendy Willems, "'Zimbabwe will never be a colony again': changing celebratory styles and meanings of independence." Anthropology Southern Africa 36, no.1-2 (2013): 22-33
} 
on why individuals join these marches in the first place ${ }^{22}$. There is some literature on timings of violence in civil wars around calendar events, if not on interstate violence. Toft \& Zhukov show that Islamist violence in the Caucuses tends to follow the religious calendar, suggesting that this kind of violence is shaped by religious events ${ }^{23}$, perhaps because the festivals increase the motivation to fight, or as Hassner argues, provide a focal point for groups to engage in violence ${ }^{24}$.

\section{National Days, Nationalism, and Conflict}

I argue that national days lead to an increase in conflict between states by increasing the salience of the nation and its previous wars and struggles for independence. This leads to greater mobilisation opportunities for domestic activists and groups with a nationalist agenda. Hawkish leaders can take advantage of the atmosphere to gain support and bargaining leverage for a confrontational international stance ${ }^{25}$, while other decision makers, seeking to appease nationalist groups at home, may find that they unwillingly increase tensions abroad.

$\underline{\text { Increases in nationalism }}$

Symbols of the nation that proliferate around national days- such as flags, music, and cultural motifs- may prime certain forms of the national identity. Schatz, Staub and

\footnotetext{
${ }^{22}$ Jonathan S. Blake, "Identity on the March: Contentious Rituals in Post-Conflict Northern Ireland." (2014). Unpublished Manuscript

${ }^{23}$ Monica Duffy Toft and Yuri M. Zhukov, "Islamists and Nationalists: Rebel Motivation and Counterinsurgency in Russia's North Caucasus." American Political Science Review 109, no.2 (2015): 222-238

${ }^{24}$ Ron E. Hassner, "Sacred time and conflict initiation." Security Studies 20, no.4 (2011): 491-520

25 A stance that puts a state into conflict with the preferences of another state
} 
Lavine show that exposure to the American flag generates 'blind patriotism'26; an emotional identification with the nation, right-wing attitudes and rejection of national criticism $^{27}$. Scholars have demonstrated that this exposure may make people more willing to favor nuclear armament ${ }^{28}$, and to be less likely to favor cooperation in international relations ${ }^{29}$. According to Butz, around national celebrations, "symbols take on a new life and have different implications when the national climate shifts from one of "banal nationalism" to one of "hot nationalism" as a result of concerted efforts to remind people of their national identity" ${ }^{30}$. At the same time, national days regularly feature military parades and the acting out of battles and war veteran stories from previous conflicts. Even on remembrance days, when these stories mourn the human costs of war, the memorials and marches all serve to make the image of military conflict extremely salient.

The result is that national days increase the public salience of the national identity and memories of wars waged to protect that identity, as well as potentially inciting more hawkish foreign policy attitudes. On a prosaic level, pacifist arguments may therefore be less likely to find currency in the media 'marketplace of ideas ${ }^{31}$ around national days, even on those days that are designed to remember the costs of war. For example

\footnotetext{
${ }^{26}$ Robert T. Schatz and Howard Lavine, "Waving the Flag: National Symbolism, Social Identity, and Political Engagement." Political Psychology 28, no.3 (2007): 329-355

${ }^{27}$ This effect may not be unidirectional however, and others have shown that exposure to national flags may reduce nationalism in those who are already more nationalistic. This literature suggests that the impact of symbols may depend on their content (for example Ran R. Hassin, Melissa J. Ferguson, Daniella Shidlovski, and Tamar Gross, "Subliminal exposure to national flags affects political thought and behavior." Proceedings of the National Academy of Sciences 104, no.50 (2007): 19757-19761; Ran R. Hassin, Melissa J. Ferguson, Rasha Kardosh, Shanette C. Porter, Travis J. Carter, and Veronika Dudareva, "Précis of implicit nationalism." Annals of the New York Academy of Sciences 1167, no.1 (2009): 135-145).

${ }^{28}$ Seymour Feshbach, "Individual aggression, national attachment, and the search for peace: Psychological perspectives." Aggressive Behavior 13, no.5 (1987): 315-325

${ }^{29}$ Elina Sinkkonen, "Nationalism, Patriotism and Foreign Policy Attitudes among Chinese University Students." The China Quarterly 216 (2013): 1045-1063

${ }^{30}$ David A. Butz, "National symbols as agents of psychological and social change." Political Psychology 30, no.5 (2009): 779-804

${ }^{31}$ Jack Snyder and Karen Ballentine. "Nationalism and the Marketplace of Ideas." International Security 21, no.2 (1996): 5-40
} 
the British Labour Party leader Jeremy Corbyn, an avowed pacifist, found himself subject to intense media attention around the 2015 anniversary of the end of WW1. Corbyn was branded in right-wing media as 'disloyal' ${ }^{32}$, while on Remembrance Sunday itself the Chief of Defence Staff launched a 'stinging attack' over Corbyn's views on nuclear disarmament ${ }^{33}$.

These changes may also give an opportunity to right-wing or nationalist activists and interest groups to push their own parochial agendas. This builds off Jack Snyder's argument in 'Myths of Empire', where groups with narrow policy interests appeal to national sentiment to push the case for war $^{34}$. In this case however the activists and groups are primarily those whose ideologies and interests can best be described as nationalistic. On national days, the heightened national sentiment means that their messages will resonate more with the public. As such at these times their size and influence will grow, and they will be more likely to hold events or try and sway government policy.

Nationalist groups have a variety of agendas. Some groups' interests lie in promoting patriotism in their country or facing off against a major geopolitical enemy. Polish nationalist groups' interests range from raising Polish youths in a "Catholic and patriotic spirit" 35 and fighting German claims for land in Poland ${ }^{36}$, to the threat from

\footnotetext{
32 "Jeremy Corbyn says spending 'shedloads' on remembering WWI soldiers is POINTLESS". The Daily Express, November 4, 2015.

33 "Jeremy Corbyn in Remembrance Sunday war with Britain's top general over nuclear button comments". The Daily Telegraph, November 8, 2015.

${ }^{34}$ Jack Snyder, "Myths of Empire: Domestic Politics and Strategic Ideology." Ithaca: Cornell University Press (1991)

${ }^{35}$ Dominika Kasprowicz, "National and Right-Wing Radicalism in the New Democracies: Poland'. 2009 workshop of the Friedrich Ebert Foundation on "Right-wing extremism and its impact on young democracies in the CEE countries"

${ }^{36}$ ibid
} 
the European Union ${ }^{37}$ and Russia ${ }^{38}$. Other nationalist groups take on an anti-American tone, for example in Russia the National Liberation Movement "combines radical antiAmericanism and anti-Semitism with Russian imperialism"39, while in Iran the regime's Revolutionary Guards have built much of their legitimacy upon antiAmerican sentiment ${ }^{40}$. Calls to strengthen the nation and denigrate foreign adversaries arise regularly on national days, not just through rhetoric in right-wing media but also marches and protests. Polish Independence Day regularly brings violence from nationalist groups, who in recent years have attacked the Russian embassy, protested the spread of liberal values ${ }^{41}$, and called for a stronger $\operatorname{army}^{42}$; Iranian celebrations of their National Day, the anniversary of the Islamic Revolution, have included rallies against America and Israel ${ }^{43}$; while in Ukraine, anti-Russian protests arose in the 2016 Victory Day celebrations of the end of WW2 ${ }^{44}$. Many of these groups have taken advantage of national days and anniversaries to target current international disputes or enemies, even if a fight against those particular enemies was not the original cause of the anniversary.

Some nationalist groups' and political parties' interests are in a specific foreign policy goal. This may be in regaining disputed territories, such as Palestinian groups in Israel, Argentinian groups over the Falklands ${ }^{45}$, or Thai Yellow Shirts over Preah Vihear ${ }^{46}$.

\footnotetext{
37 ibid

${ }^{38}$ Rafał Pankowski, Right-Wing Extremism in Poland. Friedrich-Ebert-Stiftung, 2012

39 “The Kremlin's faux 'freedom fighters"”. Foreign Policy, April 24, 2014

40 "Iran protestors hold largest anti-US rally in years". Al-Jazeera, November 4, 2013

41 "Polish Independence Day Parade Turns Violent Fourth Year In A Row". International Business Times, November 11, 2014

42 “Poland's Independence Day March Sees Drop in Violence". Radio Poland, November 12, 2015

43 "Iranians Celebrate 37 $7^{\text {th }}$ Anniversary of 1979 Islamic Revolution". Haaretz, February 11, 2016

44 "Nationalists Disrupt Victory Day Celebrations in Ukraine". Russia Today, May 9, 2016

${ }^{45}$ Matthew C. Benwell and Klaus Dodds. "Argentine territorial nationalism revisited: The Malvinas/Falklands dispute and geographies of everyday nationalism". Political Geography 30, no.8 (2011): 441-449

46 "Dispute over Preah Vihear Temple is taken up, threatening to revive Thai nationalistic fervor". Japan Times, April 28, 2013
} 
Such groups often use national days to attempt to directly press their country's claim over the territories or launch protests to their own governments to do so. For example in 2016 Filipino activists used their celebration of independence from Spain to protest Chinese actions in the South China Sea ${ }^{47}$, some attempting to plant the Philippine flag on the disputed islands ${ }^{48}$. The anniversary of Israel's creation regularly sees rallies in the Palestinian Territories ${ }^{49}$ and violent protests along Israel's borders with Gaza, Syria, and Lebanon ${ }^{50}$, while Indian and Pakistani celebrations of their independence from the UK often bring an upsurge in violence in Kashmir ${ }^{51}$.

Other groups may have interests tied up with the influence of foreign countries or foreigners on the domestic front. These may include anti-immigrant political parties such as Front Nationale in France, as well as more extreme far-right groups. Their goals range from instituting policies that restrict immigration to banishing an ethnic group or religion from the country. The Independence Day march in 2015 in Poland for example took on an anti-immigrant tone, accompanied by the burning of European Union flags ${ }^{52}$. Finally there may be groups with particular interests in national historical memory, for example War Veteran organizations. Veteran groups around the world demand proper memorialization of national conflicts and recognition of veterans' achievements ${ }^{53}$, or even take on a more wide-ranging role in national

\footnotetext{
47 “Activists Protest Against South China Sea Dispute on Independence Day”. CNN, June 12, 2015

48 "Philippine Protestors Say Harassed by Chinese During Flag Stunt". Channel News Asia, June 13, 2016

49 "Palestinian protests mark the anniversary of Israel's creation". The Christian Science Monitor, May 13, 2013

50 "Eight shot dead on Israeli borders as Palestinians mark anniversary". The Independent, May 16, 2011 "Deadly clashes at Syrian border on Mideast war anniversary". CNN, June 6, 2011.

51 "Violence Rocks Kashmir; 16 Killed". ABC News, August 13, 2015

52 "EU flag burned as tens of thousands join Warsaw nationalist demo". Daily Telegraph, November 12, 2015

${ }^{53}$ Again in France: "Veteran's anger as French bureaucracy threatens to derail 70th anniversary of D-

Day". The Daily Express, April 21, 2014
} 
politics ${ }^{54}$. Whereas groups calling for confrontational actions over territorial disputes may find themselves receiving less public sympathy around painful anniversaries that remember casualties or losses in war, these more somber times are more likely to see actions from 'memorializing' groups. And indeed veterans groups regularly use war anniversaries and independence days to launch marches or lobby for their interests ${ }^{55}$.

\section{$\underline{\text { Impact on interstate tensions }}$}

These spikes in nationalist sentiment and mobilization have the potential to lead to increases in international tensions. Firstly, regimes may exploit and play up these sentiments strategically, for their own existing international goals. Given that the public may be more nationalistic and hawkish in their attitudes around these times, and nationalist groups will be more vocally pushing their agenda, leaders may see ideal opportunities to gain more local support for more confrontational actions. Weiss argues moreover that nationalist protests - including those sparked by anniversaries can help to give states bargaining leverage ${ }^{56}$. If leaders decide that the international advantages of gaining leverage or public support over a particular foreign policy issue outweigh the disadvantages, they may choose to encourage displays of nationalism. Indeed as Lentz says, national days are "staged by the state" 57 ; states can play up the national celebrations and flag-waving at times when international tensions are highest. Iran's fervent anti-American celebration of the 1979 US Embassy siege anniversary in

\footnotetext{
${ }^{54}$ Norma J. Kriger, Guerrilla veterans in post-war Zimbabwe: Symbolic and violent politics, 1980-1987. Vol.105. Cambridge, 2003

${ }^{55}$ For example in France, "French Veterans Protest Former Nazis Laying Wreaths at Normandy Cemeteries”. JTA, May 24, 1994

${ }^{56}$ Jessica Chen Weiss, Powerful patriots: nationalist protest in China's foreign relations. OUP, 2014

${ }^{57}$ Carola Lentz, "Celebrating independence jubilees and the millennium: national days in Africa".

Nations and Nationalism, 19, no.1 (2013): 208 - 216
} 
2010 for example occurred right before confrontational US-Iran nuclear talks ${ }^{58}$. This was in contrast to the muted 2014 protest, again just prior to bilateral nuclear meetings, the difference this time being that the Rohani government was pushing a more conciliatory policy in the talks ${ }^{59}$. On one hand then, national days provide an opportunity for states in the international arena. If leaders are considering invading a neighbor or testing a missile, the potential increase in public nationalism may make them more likely to choose to do so around national days, giving them greater domestic support and international leverage.

Leaders may also respond directly to nationalist sentiment around national days. One common response is to mark the day with symbolic displays of the country's strength. These displays might not just be large-scale military rallies - but also international actions that send a message both at home and abroad that the country will stand up for itself. Kim, Kang, and Lee find for example that North Korean nuclear tests have been more likely to occur around birthdays of the 'Dear Leaders' ${ }^{60}$; arguably an attempt to boost the prestige of their leader with a display of military might. As part of its Independence Day celebrations in 2016, in the midst of the South China Sea dispute, the Indonesia regime scuttled ships from Vietnam and China. According to former Foreign Minister Marty Natalegawa, this was an explicit signal to other claimants that Indonesia would firmly protect its maritime territory ${ }^{61}$.

\footnotetext{
58 "Iran stages mass protest on anniversary of US embassy capture". The Daily Telegraph, November 4, 2010.

59 "Iranians Mark 35th Anniversary of 1979 U.S. Embassy Takeover in Tehran". Haaretz, November 4, 2013.

${ }^{60}$ Han Y. Kim, Hyoung G. Kang, and Jong K. Lee, “Can Big Data Forecast North Korean Military Aggression?" Working paper

61 "India to Sink 71 Foreign Fishing Boats Amid South China Sea Tenion". Bloomberg, August 15, 2016
} 
While it is likely that North Korea and Indonesia would likely have taken these confrontational actions at some point anyway, leaders often appear particularly keen to make reference to international disputes on national days. This is especially the case for disputed territories, which form a central part of the idea of national unity promoted on the days; whether it be the Pakistan High Commissioner to India announcing that "Pakistan will never abandon Kashmiris"62 or Tanzanian leader Kikwete warning Malawi not to "try and take away our territory" ${ }^{63}$, as part of their respective independence celebrations.

Indeed for some leaders national days may provide more of a risk than an opportunity, as the increase in nationalism and mobilization of nationalist groups puts pressure on them to take actions that might increase international tensions against their wishes. Some may have domestic political reasons to pander to nationalist sentiment, and cannot afford to ignore accusations of acting unpatriotically. For leaders who are particularly sensitive to media reactions ${ }^{64}$, the silencing of pacifist voices and amplifying of nationalist voices around national days may lead them to give in to the media clamor and adopt more hawkish policies. Other leaders may be beholden to the nationalist political lobby groups who push their agenda around these times, especially if such groups form their base of support, as is the case for Narendra Modi in India for example ${ }^{65}$. These leaders may feel under pressure to mark national days with a concession to those groups, such as referencing a territorial dispute in a commemorative speech. Finally, for leaders more concerned about keeping public order, public demonstrations may push policy in a more escalatory direction. Ciorciari

\footnotetext{
62 "Pakistan envoy raises Kashmir in Independence Day speech". The Hindu, August 14, 2015

63 “Tanzania Raises Stakes in Border Clash with Malawi”. Voice of America, July 25, 2013

${ }^{64}$ Fay Lomax Cook, Tom R. Tyler, Edward G. Goetz, Margaret T. Gordon, David Protess, Donna R. Leff, and Harvey L. Molotch. "Media and agenda setting: Effects on the public, interest group leaders, policy makers, and policy." Public Opinion Quarterly 47, no.1 (1983): 16-35

65 "The Hindu Hardline RSS who see Modi as their own". BBC Online, Oxtober 22, 2014
} 
and Weiss argue that in some cases nationalist protests will be costly to repress, and governments may need to give in to the demands of protestors, which again may include inflammatory speeches or more confrontational stances on territorial disputes ${ }^{66}$.

Pressure from nationalist groups may also result in actions that provoke a militarized response from another state. Some actions, such as attacks across borders, may themselves be acts of interstate conflict. These attacks or 'flag planting' visits to disputed areas can bring harsh diplomatic criticism, return visits, or even direct violence on the visitors ${ }^{67}$ from other claimant states. Groups who insult foreign countries, or launch attacks on embassies or on foreign citizens in nationalist riots may also spark demands for apologies ${ }^{68}$ or even reciprocal attacks from opposing publics.

While each of these incidents alone may not be enough to spark conflict, they put pressure on leaders to issue some kind of response. This may heighten interstate tensions, make cooperation less likely and increase the risk of conflict. An example of this kind of action-reaction spiral came between Pakistan and its neighbors in August 2016. When Pakistani Prime Minister Nawaz Sharif dedicated his speech on the $70^{\text {th }}$ anniversary of Pakistani independence to the "freedom of Kashmir" from Indian rule ${ }^{69}$, on India's independence celebrations the very next day Indian Prime Minister Narendra Modi hit back by criticizing Pakistani government operations against terrorist groups in Baluchistan province ${ }^{70}$. His comments drew demonstrations in the province, which borders Afghanistan, protestors taking to the streets and burning the

\footnotetext{
${ }^{66}$ John D. Ciorciari, and Jessica Chen Weiss "Nationalist Protests, Government Responses, and the Risk of Escalation in Interstate Disputes", Security Studies 25, no.4 (2016)

${ }^{67}$ Ron E. Hassner, "“To halve and to hold": Conflicts over sacred space and the problem of indivisibility." Security Studies 12, no.4 (2003): 1-33

68 "Ukraine crisis: Russia condemns attack on Kiev embassy". BBC News, June 14, 2014

69 "Indian PM Modi's Balochistan Comments Upset Pakistan". Deutsche Welle, August 15, 2016

70 "Indian PM Narendra Modi says Country will 'Never Bend Before Terrorism' in Address to Nation". IB Times, August 15, 2016
} 
Indian flag ${ }^{71}$. The tensions escalated further for Pakistan on Afghanistan's

Independence Day four days later, when Afghan demonstrators themselves angry about the Pakistani protests stormed the Bab e-Dosti 'friendship' border gate and set fire to the Pakistani flag ${ }^{72}$. This rally brought an angry diplomatic protest from Pakistan, and in retaliation government officials closed the gate for almost two weeks, only reopening after a written apology from their Afghan counterparts ${ }^{73}$. In those weeks trade was suspended across the border, badly affecting bilateral economic relations $^{74}$, and Kabul expelled 250 Pakistani workers amidst the tensions ${ }^{75}$.

An angry reaction to provocation may be especially likely when the current geopolitical opponent is also the historical enemy in a conflict memorialized by an anniversary. At these times citizens and leaders may be even more likely to see memorializing acts by its enemy as a deliberate insult or provocation, giving opportunities for nationalist groups in that country to mobilize in response. While remembrance days arouse memories of the costs of going to war, they also bring up the enormous sacrifices made to protect the country - and any weakness in the face of confrontation by the same enemy risks being seen as a betrayal of those sacrifices. This puts leaders under particular pressure to respond. In 2015 for example Croatia celebrated 'Victory Day', the twentieth anniversary of Operation Storm, a Croatian military victory over Serbian rebels in 1995 . The festivities escalated to the extent that the two countries exchanged diplomatic protest notes, the Serbians accusing Croatian officials of issuing "a call to attack and destroy Serbs". On the Croatian side,

\footnotetext{
71 "Indian Flags Set Ablaze in Balochistan Following Narendra Modi’s I-Day Diatribe against Pakistan", IB Times, August 19, 2016

72 "Pakistan-Afghanistan Border Remains Closed for Fourth Day". Fox News, August 22, 2016

${ }^{73}$ According to Pakistani newspapers ("Pakistan to reopen Chaman border tomorrow after Afghanistan tenders written apology". The News International, August 31, 2016)

74 "Traffic Across Afghanistan-Pakistan Border to Resume Thursday". VoA, August 31, 2016

75 "Afghanistan deports 250 Pakistanis due to border tension". The Times of India, August 28, 2016
} 
nationalist parades and concerts led to mass anti-Serbian chanting, while in Serbia nationalist leaders and accused war criminals burned Croatian flags in front of its embassy and the Serbian President, in a commemorative speech, harshly criticized Croatian behavior in the war $^{76}$. Yet geopolitics can take over at these times even between states that were not on opposing sides of a war anniversary. In 2015 for example, in the midst of a dispute over Russian actions in Ukraine, Russian officials called European leaders' boycott of its WWII Victory Day parade an 'insult' to the memory of Allied soldiers ${ }^{77}$, while the following year tensions between Russia and the US spilled into Moldova, when Moldovan leaders cancelled a Victory Day display of American weaponry in the face of pressure from pro-Russian organizations ${ }^{78}$.

\section{Facing up to national days}

While the heightened national sentiment and pressure from nationalist groups around national days might provide opportunities for hawkish leaders, they may become risks when states are looking to pursue more cooperative policies. At these times many states cannot fully manipulate the national sentiment and actions of their citizens and pressure groups. Even when the Iranian regime chose to play down anniversary protests in 2014, thousands of Iranians turned up on the streets chanting anti-American slogans ${ }^{79}$, while Israeli soldiers have been unable to prevent violence from spilling across borders on the country's independence day ${ }^{80}$. One problem is that national days and anniversaries are often quite deliberately embedded into the national

\footnotetext{
76 “Serbia, Croatia in Diplomatic Row Over Operation Storm”. Balkan Insight, August 7, 2015.

77 "Leaders' Snub of Moscow Victory Parade 'Insult to Soldiers', Says Russia". The Telegraph, March 23, 2015

78 “US-Russia Tension Spills over into Moldova's Victory Day". Eurasianet, May 10, 2016

79 "Flag-burning Iranians mark 35th anniversary of U.S. Embassy takeover". Los Angeles Times, September 7, 2015.

80 "Eight shot dead on Israeli borders as Palestinians mark anniversary". The Independent, May 6, 2011
} 
consciousness over many decades, and even on 'quiet' years inevitably draw celebrations. Regimes can attempt to play down festivities or clamp down upon nationalist sentiment, but this does not stop public awareness of the significance of the dates, particularly in less authoritarian states, where leaders can less easily control public opinion. The historical significance of the dates also means that for those regimes who rely on patriotism for their legitimacy, it is often difficult to discourage citizens from celebrating or launching their own 'patriotic' protests.

Even if regimes are able to exert control over the attitudes or behaviors of their populace around these times, national days are something that they need to deal with in one form or another. Leaders anticipate the rise in nationalism and the potential for mobilization (which exists even if they take no actions), and can then choose to encourage, repress, ignore, or give concessions, depending on their domestic and foreign goals. If the country is climbing the mountain of conflict, then anniversaries can help to smooth the way, providing much needed public support. However if regimes are unable to control the rise in national sentiment, or feel the need to make concessions to their electoral base or to nationalist protestors, then international tensions may rise, even if they are looking to maintain a benign international atmosphere.

Either way, national celebrations are something that leaders have to face up to every year, events that provide them with either an opportunity or a risk, by making them confront potential rises in public nationalism and decide how to respond. This is not a choice they necessarily have to make on other dates, and overall I hypothesize that it makes conflict more likely. Nationalist rhetoric often begins in the weeks before a national day, so we might expect a leap in conflict propensity in the lead-up. However, 
given that the bottom-up mechanisms discussed in the theory may take time to develop from heightened nationalism to international use of force, with an action-reaction spiral of provocation and reaction, I hypothesize that tensions that build around the day will take a few weeks or even months to develop into a full-blown militarized dispute.

- Hypothesis 1: Interstate conflict is more likely in the period following national days than at other times in the year

My theory implies two further hypotheses. Firstly, as discussed, nationalistic provocations might incite confrontation from another state and spark a spiral of provocation and reaction on both sides. However in its simplest incarnation, the theory explains how states should resort to the use of force following their own national day, in response to nationalist sentiment or action by nationalist groups. Therefore the nationalism from national days should have more of an impact on the state that initiates a conflict than a state that responds to a conflict. Secondly, we would expect the increase in nationalism to lead to conflict more in revisionist states - states looking to change the international status quo - where leaders will be more willing to take the international risks that come from allowing nationalism to run wild. Nationalist passions are also more likely to take hold in populations who feel there is an international injustice that they are looking to change.

- H2: The increased likelihood of interstate conflict after national days will be more likely to apply to states who initiate conflicts

- H3: The increased likelihood of interstate conflict after national days will be more likely to apply to states who have revisionist intent 


\section{Alternative explanations}

An alternative possibility is that national days dampen the likelihood of conflict. As discussed, some anniversaries may bring out negative memories of war and the violence it brings, and therefore reduce public support for military action around these times, leading to less conflict. Moreover, national days may not just provide opportunities for states to take more confrontational stances against their opponents, but also provide ideal occasions through which leaders can attempt to mend bilateral relations. For example Turkish President Recep Erdogan used Russia's 2016 Victory Day celebrations to write to Vladimir Putin, offering his wishes for an improvement in relations between the two countries, the first contact between the leaders since the Turkish air force shot down a Russian plane seven months earlier ${ }^{81}$. Finally, if leaders are aware of the risks national days pose, then they might be particularly careful around the celebrations of their rivals, aware that any incident might be more likely to provoke a reaction at these times than otherwise. If these factors hold, we might expect to see fewer conflicts around national days.

Another alternative is that the days make internal unrest more likely, and it is this that leads to more interstate conflict (for example through the diversionary theory of $\left.\operatorname{war}^{82}\right)$. National days are often public holidays, and groups often choose these holidays for anti-government protests (for example global May Day protests for workers' rights in $2016^{83}$ ), or even use the occasion to appear more 'patriotic' in their protests or violence. Unrest may be especially likely in countries where the day celebrates secession from a neighboring country, and therefore draws protests from the

\footnotetext{
81 “Turkish PM, President, Congratulate Russian Counterparts for National Day". Hurriyet Daily News, June 14, 2016

82 Jack S. Levy, "Domestic politics and war." Journal of Interdisciplinary History (1988): 653-673

83 "May Day Protests In Seattle, Paris, Istanbul Erupt In Violence". Huffington Post, May 2, 2016
} 
neighbor's ethnic kin $^{84}$. I test this in a number of ways in my robustness checks. To test whether there is anything special about the 'national' content of national days I also examine the impact of non-national public holidays on conflict. I also test whether national days increase the likelihood of domestic political violence, and whether the link between national days and conflict holds if states born out of secession with their neighbors are excluded.

\section{Cross-National Testing}

I first test these hypotheses by examining whether, cross-nationally, conflict is more likely to begin in the time following a country's national day than otherwise.

\section{Dependent and Independent Variables}

I measure conflict by the number of Militarized Interstate Dispute (MID) onsets in a given month between 1992 and $2010^{85}$. Most of the former Soviet states had gained their independence by this time; as such national days have stayed reasonably constant within this period. The MID measure is not perfect in many ways, but serves as a reasonable proxy for a state's conflict behavior.

My independent variable is the number of months following a national day. I create a database of one primary national day per country ${ }^{86}$. To be chosen as such the day needed to include widespread public use of national symbols and references to the

\footnotetext{
${ }^{84}$ With thanks to an anonymous reviewer for this suggestion

${ }^{85}$ Using the MID database from: http://www.correlatesofwar.org

${ }^{86}$ Using one main day has two advantages. The first is that in some places there are a large number of days that could potentially be celebrated as national occasions by someone in the population, given the number of past conflicts in some countries. Using only one per country gives a clear and conservative standard for inclusion. It also allows for a more precise and parsimonious statistical test; each MID will have only one day over the previous year
} 
nation. For most countries this is easy to code, as the country has one clear national day that is also its official National Day (for example independence days across Africa and Eastern Europe). In other countries the classification was more difficult, with two or three contenders; and I used media reports and secondary literature to determine the primary national day ${ }^{87}$. In my robustness checks I only test for those countries with one primary national day, with similar results.

\section{Statistical model}

I use a logistic regression with fixed effects, since my dependent variable is the binary occurrence (or not) of the onset of a MID in the days following a national day in a given country. Against this I regress various intervals following national days every year. I use intervals of thirty, sixty and ninety days. My expectation is that the impact of national days will be strongest in the first month, but given the chain of action and reaction I describe above, it may be that the actual impact on conflict takes longer to settle in. While I use fixed effects in my model, for easier interpretation and robustness I also use a logistic model with country dummies, with standard errors clustered by country. Given the relative low number of MIDs in my dataset, in my robustness checks I also carry out a rare events logistic regression. Finally, to examine how disputes play out over the whole year following national days, I created twelve weighted months, and carried out similar regressions. I test the relationship for the subset of 'initiators', the country coded as taking the first militarized action in the MID

\footnotetext{
${ }^{87}$ The criterion used when there was more than one contender, was simply: 'Which event normally receives the most media attention'. This criterion may miss the more relevant days for my analysis (the most widely celebrated in the media may not be the one that brings up the most nationalist sentiment); but should have no systematic bias and if anything should underestimate the strength of my results. I also remove from the dataset MIDs involving large multilateral efforts that might unfairly bias the results - but where most of the participants were not the original belligerents. On occasions where start dates in the month were unknown I took a start point of the $15^{\text {th }}$
} 
(my H2); and for 'revisionist' states, those countries who are revisionist, or seeking to change the status quo in any MID (my H3).

\section{Controls}

The regression is clean, since there are few variables that could plausibly influence both the timing of a national day and the timing of a conflict. I include one control, the time of year, since it is possible that both conflicts and national days are more likely in one season. Studies have suggested that higher temperatures increase the likelihood of conflict $^{88}$, which might therefore rise over the summer, while governments may also choose summertime for a national celebration. The below graph casts doubt on this correlation, but I include the control to be safe. In robustness checks I split time of the year by hemisphere, since summer in the north will be winter in the south.

Figure 1: Proportion of National Days and MIDs, by Month 1992 - 2010

This gives the following equation:

P(MID occurrence $=1)=\operatorname{logit}^{-1}(\alpha$ First 30/60/90 Days $+\beta$ Time of year $+\varepsilon)$

Results

\footnotetext{
${ }^{88}$ Marshall B. Burke, Edward Miguel, Shanker Satyanath, John A. Dykema, and David B. Lobell. "Warming increases the risk of civil war in Africa. "Proceedings of the National Academy of Sciences 106, no.49 (2009): 20670-20674
} 
The results suggest that conflict is more likely in the thirty and sixty days following national days (Table 1). Figure 2 shows the spread of conflict by month. From the model the odds ratio of conflict in the first thirty days following an anniversary against other times is $1.25: 1$, and 1.27:1 for the first sixty days (significant at $\mathrm{p}<0.05$ and $\mathrm{p}<0.01)$. After ninety days this increase is only minimally significant. The logistic model without fixed effects gives similar results ${ }^{89}$. The predicted probabilities from this model suggest that for all states, in the first thirty days conflicts are $27.1 \%$ more likely than the rest of the year and $27.8 \%$ more likely over the first sixty days ${ }^{90}$. Over sixty days this works out to around 0.174 more disputes per country against other times of the year (an average of 0.815 disputes over the first sixty days versus 0.641 disputes per-sixty day period for the rest of the year).

Table 1: Log Odds of Conflict in Days Following National Days against Rest of

\section{the Year}

\begin{tabular}{|c|c|c|c|}
\hline $\begin{array}{l}\text { Days since } \\
\text { national } \\
\text { day }\end{array}$ & $\begin{array}{l}\text { All- } 30 \\
\text { days }\end{array}$ & $\begin{array}{l}\text { All- } 60 \\
\text { days }\end{array}$ & $\begin{array}{l}\text { All- } 90 \\
\text { days }\end{array}$ \\
\hline 30 days & $\begin{array}{l}0.225 * * \\
(0.0900)\end{array}$ & & \\
\hline 60 days & & $\begin{array}{l}0.238 * * * \\
(0.0690)\end{array}$ & \\
\hline 90 days & & & $\begin{array}{l}0.112 * \\
(0.0627)\end{array}$ \\
\hline Month & $\begin{array}{l}-0.0360 * * * \\
(0.00791)\end{array}$ & $\begin{array}{l}-0.0375 * * * \\
(0.00795)\end{array}$ & $\begin{array}{l}-0.039 * * * \\
(0.00799)\end{array}$ \\
\hline $\mathrm{N}$ & $1,026,591$ & $1,026,591$ & $1,026,591$ \\
\hline
\end{tabular}

\footnotetext{
${ }^{89}$ The rare events logit gives even stronger results, with the log odds for thirty, sixty and ninety days at $0.245(\mathrm{p}<0.01), 0.248(\mathrm{p}<0.01)$, and $0.116(\mathrm{p}<0.1)$ respectively (appendix table 9$)$. The results do not change when using time-of-year split by hemisphere as a control (appendix table 6)

${ }^{90}$ The predicted probabilities are similar when using an OLS regression with fixed effects: an increase of $29.8 \%$ over the first thirty days and $27.3 \%$ over the first sixty days (appendix table 14 )
} 
Figure 2: Probability of Militarized Interstate Dispute by month following National Day

Figure 3: Probability of Militarized Interstate Dispute by month following National Day in revisionist state

My results show that these findings mainly hold for initiating and revisionist states. The odds ratio of conflict in the first thirty and sixty days after a national day is $1.35: 1$ and 1.32:1 for initiating states and 1.37:1 and 1.49:1 for revisionist states respectively (tables 2 and 3); the effect also lasts longer in revisionist states, remaining significant over ninety days, see Figure 3). The simple logit model suggests that this means conflicts are $37.6 \%$ more likely in the first thirty days and $34.3 \%$ more likely in the first sixty days for states that initiate conflicts than the rest of the year, and $39.3 \%$ and $49.9 \%$ more likely respectively for revisionist states. Notably, the results are insignificant for those states that do not initiate the conflicts, and/or are not revisionist ${ }^{91}$.

Table 2: Log Odds of Conflict in Days Following National Days against Rest of the Year: Initiating State ${ }^{\mathbf{2}}$

\begin{tabular}{|c|c|c|c|c|c|c|}
\hline $\begin{array}{l}\text { Days } \\
\text { since } \\
\text { national } \\
\text { day } \\
\end{array}$ & $\begin{array}{l}\text { Initiating } \\
\text { State- } 30 \\
\text { days }\end{array}$ & $\begin{array}{l}\text { Initiating } \\
\text { State - } 60 \\
\text { days }\end{array}$ & $\begin{array}{l}\text { Initiating } \\
\text { State - } 90 \\
\text { days }\end{array}$ & $\begin{array}{l}\text { Non- } \\
\text { Initiating } \\
\text { State- } 30 \\
\text { days } \\
\end{array}$ & $\begin{array}{l}\text { Non- } \\
\text { Initiating } \\
\text { State - } 60 \\
\text { days }\end{array}$ & $\begin{array}{l}\text { Non- } \\
\text { Initiating } \\
\text { State - } 90 \\
\text { days }\end{array}$ \\
\hline 30 days & $\begin{array}{l}0.299 * * * \\
(0.121)\end{array}$ & & & $\begin{array}{l}0.119 \\
(0.135)\end{array}$ & & \\
\hline 60 days & & $\begin{array}{l}\text { 0.281**** } \\
(\mathbf{0 . 0 9 4 4 )}\end{array}$ & & & $\begin{array}{l}0.162 \\
(0.101)\end{array}$ & \\
\hline 90 days & & & $\begin{array}{l}0.140 \\
(0.0863)\end{array}$ & & & $\begin{array}{l}0.0645 \\
(0.0913)\end{array}$ \\
\hline Month & $-0.0495 * * *$ & $-0.0510 * * *$ & $-0.0504 * * *$ & $-0.0210 *$ & $-0.0224 *$ & $-0.0216^{*}$ \\
\hline
\end{tabular}




\begin{tabular}{llll|lll} 
& $(0.0110)$ & $(0.0110)$ & $(0.0111)$ & $(0.0114)$ & $(0.0115)$ & $(0.0115)$ \\
$\mathrm{N}$ & 963,728 & 963,728 & 963,728 & 927,684 & 927,684 & 927,684
\end{tabular}

Standard errors in parentheses

$* * * \mathrm{p}<0.01, * * \mathrm{p}<0.05, * \mathrm{p}<0.1$

Table 3: Log Odds of Conflict in Days Following National Days against Rest of the Year:

\section{Revisionist State ${ }^{93}$}

\begin{tabular}{|c|c|c|c|c|c|c|}
\hline $\begin{array}{l}\text { Days since } \\
\text { national day }\end{array}$ & $\begin{array}{l}\text { Rev State- } \\
30 \text { days }\end{array}$ & $\begin{array}{l}\text { Rev State- } \\
60 \text { days }\end{array}$ & $\begin{array}{l}\text { Rev State- } \\
90 \text { days }\end{array}$ & $\begin{array}{l}\text { Non-Rev } \\
\text { State- } 30 \\
\text { days }\end{array}$ & $\begin{array}{l}\text { Non-Rev } \\
\text { State- } 60 \\
\text { days }\end{array}$ & $\begin{array}{l}\text { Non-Rev } \\
\text { State- } 90 \\
\text { days }\end{array}$ \\
\hline 30 days & $\begin{array}{l}\text { 0.316** } \\
(\mathbf{0 . 1 3 5 )}\end{array}$ & & & $\begin{array}{l}0.145 \\
(0.121)\end{array}$ & & \\
\hline 60 days & & $\begin{array}{l}\mathbf{0 . 3 9 9} * * * \\
(\mathbf{0 . 1 0 3 )}\end{array}$ & & & $\begin{array}{l}0.106 \\
(0.0933)\end{array}$ & \\
\hline 90 days & & & $\begin{array}{l}0.243 * * \\
(0.0955)\end{array}$ & & & $\begin{array}{l}0.0087 \\
(0.0834)\end{array}$ \\
\hline Month & $\begin{array}{l}-0.0350 * * * \\
(0.0123)\end{array}$ & $\begin{array}{l}-0.0387 * * * \\
(0.0125)\end{array}$ & $\begin{array}{l}-0.0387 * * * \\
(0.0125)\end{array}$ & $\begin{array}{l}-0.0361 * * * \\
(0.0103)\end{array}$ & $\begin{array}{l}-0.0364 * * * \\
(0.0103)\end{array}$ & $\begin{array}{l}-0.0355^{* * *} \\
(0.0104)\end{array}$ \\
\hline $\mathrm{N}$ & 825,232 & 825,232 & 825,232 & 993,130 & 993,130 & 993,130 \\
\hline
\end{tabular}

Standard errors in parentheses

$* * * \mathrm{p}<0.01, * * \mathrm{p}<0.05, * \mathrm{p}<0.1$

\section{Robustness}

Firstly I test whether these results only hold for countries with one primary National

Day. The results for the logistic model with fixed effects are if anything slightly

higher, with odds ratios for all states of $1.37: 1$ for thirty days $(\mathrm{p}<0.01), 1.31: 1$ for sixty days $(\mathrm{p}<0.01)$ and 1.19:1 over ninety days $(\mathrm{p}<0.05)$. I also show that the result holds only in this two-month period, and is not just an artifact of the data. The odds ratios over each two-month period following a national day demonstrates that the only significant increase in odds comes between the month before the national day and the month after, and the only significant drop comes between the second and third month.

\footnotetext{
93 The coefficients are significantly different between revisionist and non-revisionist in 60 and 90 days $(\mathrm{p}<0.05$ and $\mathrm{p}<0.1)$
} 
There is also no significant increase when testing the impact of the eighth month directly on MID propensity (the other apparent spike in Figure 2) ${ }^{94}$.

Table 4: Odds for Rise/Drop in MIDs Between-Months Following National Day ${ }^{95}$

\begin{tabular}{|c|c|c|c|c|c|c|c|c|c|c|c|c|}
\hline $\begin{array}{l}\text { Month } \\
\text { change }\end{array}$ & $12-1$ & $1-2$ & $2-3$ & $3-4$ & 4-5 & $5-6$ & $6-7$ & $7-8$ & $8-9$ & $9-10$ & $10-11$ & 11-12 \\
\hline $\begin{array}{l}\text { Log } \\
\text { Odds }\end{array}$ & 0.23 & $\begin{array}{l}- \\
0.04\end{array}$ & -0.31 & 0.13 & $\overline{-}-05$ & 0.02 & 0.04 & $\begin{array}{l}- \\
0.05\end{array}$ & 0.14 & $-\overline{0}-13$ & -0.17 & 0.18 \\
\hline$p$-value & 0.06 & 0.75 & 0.02 & 0.33 & 0.69 & 0.90 & 0.73 & 0.33 & 0.27 & 0.21 & 0.18 & 0.13 \\
\hline
\end{tabular}

To further substantiate my results and test whether this may just be a result of protests on public holidays I examine the impact of non-national, non-symbolic, and secular public holidays. I again choose one for each country, varying between days like May Day, International Women's Day, and various New Year's Days. Periods following these holidays show no significant increase in conflict, even for revisionist states $^{96}$. National days also have no effect on the likelihood of internal armed conflict ${ }^{97}$ or major episodes of political violence ${ }^{98}$, and the overall positive results still hold when we exclude country-years with ongoing internal conflict ${ }^{99}$. The results also hold when we exclude 'secessionist' states ${ }^{100}$. While the results do not account for all instances of domestic unrest, these tests suggest that domestic factors are not the main drivers of the national day effect.

The theory that international belligerence is not only driven by top-down manipulation but also bottom-up pressure might be less plausible if the national day-increase in MIDs is seen only in authoritarian states. In these regimes leaders have greater ability

\footnotetext{
${ }^{94}$ See appendix table 26

95 Using a non-fixed effects logit

${ }^{96}$ See appendix table 17

${ }^{97}$ UCDP database of internal armed conflicts (Therése Pettersson and Peter Wallensteen, "Armed Conflicts, 1946-2014". Journal of Peace Research 52, no.4, 2015. See appendix table 25

${ }^{98}$ Center for Systemic Peace on "independence, interstate, ethnic, and civil; violence and warfare", http://www.systemicpeace.org/inscrdata.html. See appendix table 24

${ }^{99}$ See appendix table 26

100 See appendix table 27
} 
to manipulate the importance of a celebration, and less incentive to pander to pressure groups or public opinion. Testing by regime type ${ }^{101}$ shows however that while established autocracies do show some minimally significant increases over sixty days (odds ratio of 1.30:1, but non-significant over thirty days), it is only in established democracies that national days appear to have a consistently strong effect on conflict propensity (1.38:1 over thirty days and 1.32:1 over sixty days). Results are nonsignificant for hybrid regimes ${ }^{102}$.

I also test for the robustness of the 'Revisionist' measure by looking at another plausible measure of a country's concerns about the status quo, military expenditure. National days only have a significant impact on the likelihood of conflict in those countries where military expenditure is above the mean (odds ratio of 1.31:1 over the first sixty days $(\mathrm{p}<0.01)$, versus a non-significant $1.17: 1$ when below $)^{103}$. The conflicts that occur in the sixty days following a national day also see a small but significantly greater level of fatalities (around 0.092 higher on a 0-6 scale, $\mathrm{p}<0.05$ ) and hostility level (around 0.152 higher, on a 1-5 scale, $\mathrm{p}<0.05)^{104}$.

We might expect that not only will national days increase the likelihood of conflict with any country, but that this effect will be particularly large for 'dyadic' days, when the current opponent was also the opponent in the war anniversary. Unfortunately this effect is difficult to test using the national days used in this data, which mainly celebrate independence from a distant colonial power, rather than anniversaries of war

\footnotetext{
${ }^{101}$ Polity IV index (http://www.systemicpeace.org/polityproject.html), which codes states as established autocracies if their score is between -10 and -6 , hybrid regimes between -5 and 5 , and established democracies between 6 and 10

102 See appendix table 15. Rare events logits support these results (appendix table 16)

${ }^{103}$ See appendix table 20

${ }^{104}$ See appendix tables 22 and 23
} 
against a current enemy. As such ${ }^{105}$ the number of conflicts in total that states have against the 'target' of the national day are very few (only 34, or 0.025 of the MIDs). These are not significantly more likely to occur in the first two months, as we might expect given the small sample size. I explore the peculiar danger of dyadic days in the case study below.

\section{Discussion}

The results show that there is a clear increase in the propensity of interstate conflict following national days. As figures 2 shows, there is a (albeit non-significant) jump in the month leading up the day, before conflict peaks in the next month. This suggests that the likelihood of a dispute builds up in the weeks before the celebration but does not fully emerge until the next two months. Militarized disputes are almost $30 \%$ more likely at these times, an effect similar to the jump in conflict propensity we would expect from an autocratic regime change ${ }^{106}$. This is especially clear for states with revisionist intent (or high military spending), who show as much as a $45 \%$ greater likelihood of conflict in the first two months after a national day against the rest of the year. The finding suggests that national days have a particular effect on conflict in states not happy with the status quo. This is consistent both with the argument that greater nationalist sentiment, feelings of injustice and the need to regain lost territories push states towards more conflict in this period, and also that more belligerent states will be more likely to take advantage of the celebration to signal their resolve.

The fact that we see no impact of non-national holidays on the likelihood of conflict indicates that there is something special about national festivals that encourages

\footnotetext{
105 And given that the dyadic MID dataset only runs to 2001

${ }^{106}$ Andrew. J. Enterline "Regime changes, neighborhoods, and interstate conflict, 1816-1992". Journal of Conflict Resolution, 42, no.6 (1998): 804-829
} 
interstate violence, and that this effect does not appear to be driven by greater domestic armed conflict. Conflicts that occur in the first two months are more violent than at other times, which suggests moreover that not only does nationalism incite more conflict, but also that conflict linked to these sentiments may provoke a different type of violence to other times. Finally, the fact that the national day effect is not limited to autocracies, and indeed is stronger in institutionalized democracies, with less centralized control over the media and more electoral pressures, suggests that the national day effect is likely to be driven to some extent from below, from public opinion or nationalist interest groups.

\section{National Anniversaries in Japan and China}

The run of war anniversaries in Japan and China provides an excellent case in which to analyze the mechanisms of the theory, and also the alternative argument that somber anniversaries might lead to a dampening of international tensions. It is also a case, where, at least for China, scholars have explicitly argued that the regime is manipulating public nationalism for its own international purposes ${ }^{107}$, and is therefore a challenging case to show that these days also have a bottom-up impact. The war anniversaries discussed are dyadic - in that the original opponents of the anniversary (Japan and China) are also current geopolitical opponents - so goes beyond the intricacies possible in the cross-national test above, which looks only at how national days affect the likelihood of conflict against any opponent. A dyadic case like this gives some insight on how national days may be particularly dangerous when current geopolitical rivals are also historical rivals. However as this case will show, the mechanisms involved are the same, whether they are rivals or not. National days lead

107 Weiss (2014) 
to an increase in salience of the nation and its past conflicts, which increase pressure on the government to take confrontational actions. If leaders choose to encourage and coopt this pressure, or make concessions, then international tensions increase.

It is hard to show the counterfactual; that tensions would not have increased without the anniversaries; and it is plausible that the disputes discussed would have taken place in some form nonetheless. It is also worth noting that despite tensions between China and Japan, there have been very few serious military incidents between the two countries since WWII. So while national occasions have contributed towards an increase in tensions in the region, the case shows that spikes in nationalism are not an automatic recipe for war, since even with these disputes there have been enough countervailing factors to prevent them from breaking out into open conflict.

I focus on three painful national days in successive summer months, $7^{\text {th }}$ July (the anniversary of the 'Marco Polo Bridge' incident, the 1937 Japan invasion of China), $15^{\text {th }}$ August (anniversary of Japan's 1945 surrender to Allied forces), and not least the unofficial 'National Humiliation Day' on $18^{\text {th }}$ September (anniversary of the Mukden Incident, the Japanese invasion of Manchuria in 1931) ${ }^{108}$. The Marco Polo Bridge and Mukden incident are particularly significant in China, and featured extensively in history textbooks since the 1990s. Marco Polo Bridge remembrance ceremonies are held in Beijing and covered in front-page news ${ }^{109}$, while on the Mukden anniversary sirens are sounded across cities in China at $10 \mathrm{am}^{110}$. The $15^{\text {th }}$ August is

\footnotetext{
108 William Callahan, "History, identity, and security: producing and consuming nationalism in China." Critical Asian Studies 38.2 (2006): 179-208. This does not include $3^{\text {rd }}$ September, a new holiday in China

109 “On a wartime anniversary, China steps up its anti-Japan PR campaign”, Time, July 7, 2014

110 "China marks anniversary of Japanese occupation", Japan Today, September 19, 2013
} 
commemorated more widely in Japan, with highly publicized annual memorial services $^{111}$.

As we might expect, media references to painful national historical events increase around the anniversaries. Figure 4 shows the average monthly references in the Chinese state newspaper the People's Daily to the 'Nanjing Massacre' and 'Marco Polo Bridge Incident'. The references are notably higher around national anniversaries, even away from the specific anniversaries of the incidents in early July and midDecember.

\section{Figure 4: Mentions of Past Japanese Violence in the People's Daily by Month,} 1980 - 2011

It is not just memorials of painful events. On the $70^{\text {th }}$ anniversary of the end of the Second World War in Asia, the landscape in China was saturated with images of conflict with Japan. The government required Chinese national flags to be hung around the streets in Beijing to "further enhance the celebrations"112, and the parade featured an enormous show of military might ${ }^{113}$. There was little doubt as to the target in the 'Commemoration of the $70^{\text {th }}$ Anniversary of Victory of Chinese People's Resistance Against Japanese Aggression and World Anti-Fascist War ${ }^{114}$. The airwaves were at times literally filled with memories of fighting the Japanese. In the lead-up the government produced " 10 movies, 12 TV series, 20 documentaries and three cartoon

111 “Emperor voices 'deep remorse' over war at $70^{\text {th }}$ anniversary of surrender", Japan Times, August 15, 2015

112 "National flags required to be hung for victory celebrations". Global Times, September 1, 2015

113 "China shows off missile 'able to destroy aircraft carriers' at massive WW2 parade". The Daily

Telegraph, September 3, 2015

114 “China stages cultural gala for V-Day celebration”. Xinhua Online, September 3, 2015 
series" about the Japanese invasion ${ }^{115}$. And over the week of the anniversary, China's top television channels suspended all entertainment shows, replacing them with programs about the war ${ }^{116}$.

Chinese media is more likely to refer to Japan as an enemy around anniversaries ${ }^{117}$, as well as the US, a geopolitical opponent but not the target of the anniversary (figure $5)^{118}$. The media also discusses territorial disputes more around national anniversaries, as shown in Figure 6, especially the disputed Diaoyu/Senkakus islands (the use of 'Diaoyu' with 'Japan' in the People's Daily is significantly higher after anniversaries ${ }^{119}$, while mentions of 'Philippines' in the disputed 'South China Sea' also rose very slightly ${ }^{120}$ ).

Figure 5: Mentions of Threat from Geopolitical Opponent in People's Daily by Month, 1980 - 2011

Figure 6: Average Mentions of "Diaoyu' and 'Japan" and "South China Sea' and 'Philippines" in People's Daily by Month, 1980-2011

\author{
$\underline{\text { Yasukuni Shrine }}$
}

\footnotetext{
115 “China looks to TV, theaters to mark WWII anniversary”. Xinhua Online, July 6, 2015

116 "Where is 'Dad, Where Are We Going?': Scheduled TV Programming to Halt During 70th Anniversary Celebrations". The Beijinger, August 21, 2015.

${ }^{117}$ Again using a simple regression in the month after, $\mathrm{p}<0.0001$. See appendix table 27

$118 \mathrm{p}=0.029$

119 In the month after anniversaries, see appendix table 28

${ }^{120}$ Albeit non-significantly
} 
One prominent example of how nationalist activists have used anniversaries to push for actions that have then sparked bilateral tensions is visits to the Yasukuni Shrine. In 1978 Japanese priests interred the souls of fourteen Class A war criminals in the shrine, and visits from Japanese leaders on the $15^{\text {th }}$ August anniversary of the end of WW2 have since become a controversial issue amongst nationalist and liberal Japanese groups, as well as for China and Korea. Daiki argues that rightist intellectuals, politicians and activists in Japan see the visits as central to a patriotic memory they wish to preserve, and together form influential pressure groups ${ }^{121}$. Every year in the build up to the anniversary Japanese lobby groups and conservative newspapers pressurize politicians to commemorate the anniversary by carrying out an official visit and offering. The Japan Association for Bereaved Families (JABF) for example, a group set up to support families of deceased WW2 soldiers, with an estimated membership of around one million, use demonstrations, petitions and informal lobbying in their goal to persuade Prime Ministers to visit the shrine on the anniversary ${ }^{122}$. According to Smith, the JABF has been "a major source of votes for the LDP"123, and was a particularly powerful pressure group for Koizumi in his time as Prime Minister ${ }^{124}$.

While leaders have attended on other dates, notably the Spring and Autumn festivals, pressure from nationalist groups is particularly strong around the $15^{\text {th }}$ August anniversary. The ceremony is the year's most prominent, and since 1998 significantly more Cabinet and Diet members have attended on the anniversary than at any other

\footnotetext{
${ }^{121}$ Daiki Shibuichi, "The Yasukuni Shrine dispute and the politics of identity in Japan: why all the fuss?." Asian Survey 45, no.2 (2005): 197-215

122 Daiki Shibuichi (2005)

123 The Liberal Democratic Party. Sheila Smith, Intimate Rivals: Japanese Domestic Politics and a Rising China. Columbia University Press, 2015: 70, 72

${ }^{124}$ Daiki Shibuichi (2005)
} 
time $^{125}$. During the presidential election in 2001 Koizumi made a phone call to the chairwomen of the JABF asking for its support in exchange for a pledge to visit the shrine on the anniversary ${ }^{126}$. He faced intense pressure from China and Korea not to attend, and was persuaded by his aides to go two days earlier. The Japan Times said of the change: "it only serves to make many Japanese suspect that the nation's top official lacks integrity" 127 , and in a survey in Japan at the time, while many approved of the switch, $23.3 \%$ believed that he should have attended on the anniversary, a small but significant number for a leader relying on the support of nationalist groups ${ }^{128}$. He later confessed to his constituents to feeling 'ashamed' that he had not attended on the anniversary itself $^{129}$. When he did visit on the anniversary in 2006 Koizumi said: "I think today is the appropriate day to go"130. Nakasone was perturbed by the angry Chinese response to his visit on the anniversary in 1985, and chose not to go for the remainder of his tenure. His decision not to attend on the anniversary brought him death threats from right-wing activists ${ }^{131}$. There is no evidence that similar threats were made for his nonattendance on any other days of the year.

While the visits have not directly led to militarized disputes, they have invariably strained relations with China (and Korea), in the expected action-reaction spiral of escalation. Since priests interred the souls of the war criminals, the Chinese response to official visits has consisted of media indignation, diplomatic protests, and on occasion, public demonstrations. When in 1985 Nakasone commemorated the $15^{\text {th }}$ August anniversary at the shrine, the visit provoked a furious media and diplomatic

\footnotetext{
${ }^{125}$ Erika. M. Pollmann, "The Politics of Visiting the Yasukuni Shrine: Explaining Japanese Politicians' Behaviors." Georgetown Journal of Asian Affairs, Winter (2016), 123-152

126 Pollman (2016)

127 "Mr. Koizumi’s poor choice", Japan Times, August 14, 2001

128 August 2001 Kyodo Press Immediate Poll quoted in Shibuichi, Daiki (2005)

129 “JAPAN: Debate Far from Over after Premier's Trip to Shrine”, IPS News Agency, August 14, 2001

130 “Koizumi ignores protests, visits Yasukuni shrine", Taipei Times, August 16, 2006

${ }^{131}$ Taipei Times (2006)
} 
response in China ${ }^{132}$. One month later, thousands of Chinese university students protested in Beijing over the visit, sparking nationwide demonstrations to commemorate the $18^{\text {th }}$ September anniversary. Reilly argues that these protests led to a more hawkish Chinese position towards Japan and increased diplomatic confrontations between the two countries ${ }^{133}$.

China-Japan relations reached perhaps their lowest ebb in recent years following the election of Koizumi, who visited Yasukuni every year between 2001 and 2006. Visits drew official protests, led to the suspension of bilateral summit meetings ${ }^{134}$ and arguably contributed to the build-up in tension that culminated in intense anti-Japan protests against the country's bid for United Nations Security Council membership in 2005. Not all of these visits were on the anniversary however, and after the wrath from China and Korea in 2001, Koizumi prudently attended the shrine in other months until 2006, when he once again attended on the $15^{\text {th }}$ August. While each visit drew an angry response, Chinese domestic attention was higher around the anniversaries, as shown by figure 7, with the exception of 2005 (a time of high tension over the UNSC vote). Over time Chinese media have begun to pay close attention to the Japanese response in midAugust - such as which ministers have attended and the size of the offering something not done to the same extent around the other festivals ${ }^{135}$. Before Abe came to power, a report by Michael Green and Shinjiro Koizumi of the Center for Security and International Studies argued that: "If Abe visits Yasukuni on Aug. 15, it is certain that China and South Korea will close the door to talks. But, the calculation is that if Abe chooses another date, it provides an opportunity for China and South Korea to say

132 "Nakasone's Visit to Wartime Shrine Criticized". Los Angeles Times, August 16, 1985

133 James Reilly, Strong society, smart state: The rise of public opinion in China's Japan policy. Columbia University Press, 2013

134 "Koizumi shrine visit stokes anger". BBC Online, August 16, 2006

135 "South Korea, China React to Yasukuni Shrine Visits," The Wall Street Journal, August 15, 2014 
that Abe's visit is not as bad as that of Koizumi, and they can convince their people to

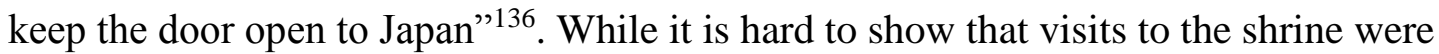
responsible, data from the Japanese Coast Guard suggests that in August 2013 and 2014, when Japanese ministers visited the shrine, there was a marked increase in Chinese patrols in Japanese territorial waters around the disputed Diaoyu/Senkaku islands ${ }^{137}$.

Figure 7: Articles about Prime Minister Koizumi's visits to the Yasukuni Shrine in the People's Daily in the thirty days following the visits. Dark blue represent visits around the August anniversary

Both the Chinese and Japanese governments have dealt with these pressures strategically. Japanese leaders have often chosen not to attend the Yasukuni Shrine when particularly concerned about bilateral relations, and Chinese responses have also varied in their intensity depending on the international situation. Weiss argues that the CCP protested strongly against the Nakasone visit to Yasukuni and permitted student protests on the September anniversary for bargaining reasons. Protests served in part as an attempt to put pressure on the Japanese as part of bilateral trade negotiations, and Weiss reasons that Beijing made the choice to react to the shrine visit and allow protests on the anniversary because it had already decided to take a strong stance ${ }^{138}$.

Yet strategic manipulation of the anniversary cannot be the whole story. In Japan most visits to the Yasukuni shrine have come despite international tensions, not because of

${ }^{136}$ Michael, J. Green and Shinjiro Koizumi, "U.S.-Japan Relations: Enter Abe Stage Right”, CSIS. Comparative Connections, 8 no.3 (2006): 1-9, 3

${ }^{137}$ Data from http://www.kaiho.mlit.go.jp/senkaku/index.html

138 Weiss (2014) 
them, in an attempt to placate domestic pressure groups. Abe remained deliberately ambiguous about the issue on his first term in office, to avoid disrupting relations with China and to gain domestic support with liberal factions ${ }^{139}$, but chose to visit in his second term as those domestic constraints weakened, despite the lack of any obvious international benefits $^{140}$. In 2005 Koizumi, seeking conservative support in Japan, even visited just days before his Foreign Minister was scheduled to meet his counterparts in China to strengthen Sino-Japanese cooperation ${ }^{141}$. Beijing cancelled the meetings. On occasions China's harsh response to Yasukuni visits have also gone against its international priorities. Koizumi's visits to the shrine were arguably the cause of the poor relations between the countries from $2001^{142}$, the 1983 critical response to the visit came in the face of discussions around the extension of $\$ 2$ billion loans from Japan to China ${ }^{143}$, and Abe was subject to intense private Chinese lobbying to avoid shrine visits when he came to office; presumably because the CCP did not want to continue to have the diplomatic fallouts that such visits would bring ${ }^{144}$.

The Yasukuni case is an example of how concessions to domestic nationalism around prominent national days pushed Japanese leaders into taking actions that increased bilateral tensions. In this case, in contrast to my $\mathrm{H} 2$, those actions were not themselves militarized, but served to spark a reaction from China that endangered cooperation over bilateral disputes and raised the risk of conflict.

\section{Diaoyu/Senkaku islands}

\footnotetext{
${ }^{139}$ Mong Cheung, "Japan's Domestic Politics and China Policy: The Yasukuni Controversy (200607)." The Journal of Contemporary China Studies, no.2 (2013): 25-46

140 “Abe's Yasukuni visit: the view from Japan”. East Asia Forum, January 24, 2014

141 "Relations Fray as Japan Criticizes Chinese Official's Snub". New York Times, May 25, 2005

142 Kent E. Calder, "China and Japan's simmering rivalry." Foreign Affairs, no.2 (2006): 129

143 “Japan Loans To China”. New York Times, May 24, 1983

${ }^{144}$ Mong Cheung (2013)
} 
Nationalist groups and citizens in both countries have also attempted to influence decision makers over the disputed Diaoyu/Senkaku islands. In Japan, pressure has often come from groups of conservative politicians, who have used various provocative actions to bolster Japan's claims, such as landing on the islands or building lighthouses ${ }^{145}$. In China, Baodiao ('Protect the Diaoyus') activists are a loose group of individuals who began in Taiwan in the 1970s, before spreading to Hong Kong and the mainland ${ }^{146}$. They seek to strengthen the mainland and Taiwanese claims over the islands, through public statements, protests at government offices and landings. Previous attempted landings on the islands have led to arrests by the Japanese Coast Guard and subsequent diplomatic protests (notably after a Baodiao activist drowned in 1996) ${ }^{147}$.

These groups played important roles in 2012, where growing tensions between China and Japan were closely tied to the anniversaries. On the $7^{\text {th }}$ July, Japanese Prime Minister Noda announced that his government would buy three of the Diaoyu/Senkaku islands from their private owner. The decision came in response to Tokyo's governor Shintaro Ishihara (leader of the nationalist Sunrise party), who had announced in April his own plan to purchase the islands ${ }^{148}$. There is no evidence that Noda's announcement that he would nationalize the islands was deliberately timed to take place on the $7^{\text {th }}$ July. However Chinese media reports and social media users took particular exception to the fact that this day had been $\operatorname{chosen}^{149}$; seeing it as a

\footnotetext{
${ }^{145}$ In August 1978 for example

146 James. Reilly, "The rebirth of minjian waijiao: China's popular diplomacy toward Japan." Japan Policy Research Institute Working Paper, 115 (2009)

147 "Hong Kong Activist Drowns During Protest". LA Times, September 27, 1996

148 “Tokyo's rightwing governor plans to buy disputed Senkaku Islands". The Guardian, April 19, 2012

149“日本在七七事变纪念日宣布欲将钓鱼岛国有化” (“Japan announces nationalisation of the Diaoyu Islands on the anniversary of the Marco Polo Bridge Incident”). Sina, July 11, 2011. “日本故意选七七
} 
deliberate insult, and even explicitly referred to it as a "second Marco Polo Bridge incident" ${ }^{\prime 50}$. While the official Chinese response was stern but muted, tensions grew and on the August $15^{\text {th }}$ anniversary Baodiao activists landed on the disputed islands. The Japanese coastguard arrested the activists, before quickly deporting them. Publicity of the landing in China (and reciprocal landings from Japanese nationalist groups and politicians) led to widespread anti-Japan protests and a notable strengthening of CCP rhetoric.

On the $11^{\text {th }}$ September, Noda purchased the islands, sparking further diplomatic and online public protests. The Chinese government therefore faced a decision about how to approach the $18^{\text {th }}$ September anniversary. With tensions high, there were calls across the country for demonstrations, and the government acquiesced, while attempting to keep the protests under control. According to Gries, Steiger and Wang, social media activity about the islands peaked at the time one might expect - around the purchase on the $11^{\text {th }}$ of September ${ }^{151}$. The huge and often-violent countrywide protests did not take place until the anniversary weekend however, particularly on the day itself ${ }^{152}$, and Cairns and Carlson show that calls for action on Weibo peaked on that weekend (as they did on the $15^{\text {th }}$ of August for the first wave) $)^{153}$. Gries and colleagues argue that diplomatic and military escalation was a direct result of these protests, and show that Chinese military actions in the East China Sea, including sending warships to the area, began to spike after the anniversary protests had begun,

事变纪念日宣布钓鱼岛“归日本”’(“Japan deliberately announces nationalisation of Diaoyu Islands on anniversary of the 'Marco Polo Bridge Incident”'). Wushu Net.

150 “日本将钓鱼岛“国有化”是第二次“卢沟桥事变”” (“Japan nationalising the Diaoyu islands is a second 'Marco Polo Bridge Incident'”). People's Net, July 14, 2012.

${ }^{151}$ Peter H. Gries, Derek Steiger, and Tao Wang, "Popular Nationalism and China's Japan Policy: the Diaoyu Islands protests, 2012-2013”. Journal of Contemporary China (2015): 1 - 13, 10

152 Gries, Steiger, and Wang (2015)

${ }^{153}$ Christopher Cairns and Allen Carlson, "Real-world Islands in a Social Media Sea: Nationalism and Censorship on Weibo during the 2012 Diaoyu/Senkaku Crisis”. The China Quarterly 225 (2016): 23-49, 37 
increasing from the $17^{\text {th }}$ of September to a peak on the $1^{\text {st }}$ of October ${ }^{154}$. The Chinese government also cut bilateral diplomatic ties ${ }^{155}$, carried out military exercises in the area $^{156}$, and increased patrols around the islands, as in turn did the Japan Coast Guard $^{157}$. Over the following months the strained diplomatic relations and increased Chinese presence in the area led to several 'close calls' between the two militaries. In December, Japan scrambled fighter jets to meet a Chinese plane that had entered the islands' airspace ${ }^{158}$, while in the next month the Chinese navy twice locked missile radars onto Japanese ships ${ }^{159}$.

It is difficult to show for sure whether the Chinese government manipulated the anniversaries in August and September to gain support for their existing decision to act more assertively around the islands, or if the increased presence was in part in response to nationalist groups' actions on these days. On one hand, the only occasion Beijing has actively permitted mainland Baodiao activists to sail to the Senkaku/Diaoyu islands was in this period, and Cairns and Carlson show that Chinese government censorship on Weibo about 'Diaoyu islands' dropped dramatically in the middle of August, just around the first landing on the islands, suggesting that the Chinese government was hoping to promote bottom-up activism for its own purposes $^{160}$. On their side Japanese leaders appeared to make efforts to calm bilateral tensions, despite the pressures of the $15^{\text {th }}$ August anniversary. Public opinion surveys at the time showed that almost $70 \%$ of Japanese respondents thought the government

\footnotetext{
${ }^{154}$ Gries, Steiger, and Wang (2015), pg243 and pg272

155 Weiss (2014)

156 "China 'sharpens response', starts military exercises near disputed islands“. Russia Today, October 19, 2012

${ }^{157}$ Sheila A. Smith, "A Sino-Japanese Clash in the East China Sea”. Council of Foreign Relations, Contingency Planning Memorandum No.18, (2012)

158 "Japan scrambles fighter jets after Chinese plane seen near disputed islands“. CNN, December 13, 2012

159، Tensions Flare as Japan Says China Threatened Its Forces“. Wall Street Journal, February 5, 2013

${ }^{160}$ Cairns and Carlson (2016)
} 
was weak in deporting rather than convicting the Baodiao landers ${ }^{161}$. So as not to reignite tensions after the anniversary a year later, the Japanese coastguard prevented activists from Ganbare Nippon from landing on the islands ${ }^{162}$.

On the other hand, even authoritarian governments like China, never mind democracies like Japan, have sometimes been unable to stop citizen expressions of nationalism. On some occasions the Chinese Marine Department have been unable to prevent Baodiao activists, particularly from Hong Kong and Taiwan, from landing on the islands, such as in July 2012 when activists used a Taiwanese escort to bypass Chinese restrictions ${ }^{163}$. And even when China has deliberately played down tensions and attempted to stifle public displays of nationalism, like in 2010, the September anniversary still saw (albeit small) groups of anti-Japan protests throughout China ${ }^{164}$. Johnston, as well as Gries and colleagues, argue that in 2012, because of the sensitive nature of the September $18^{\text {th }}$ anniversary, the costs to the CCP's domestic legitimacy of preventing the expression of nationalism were just too high ${ }^{165}$. This appears to be backed up by Cairns and Carlson's findings that government censorship of the dispute was high over the anniversary weekend. If the Communist Party was trying to promote protests in August, it was certainly not doing so in September ${ }^{166}$.

The conclusion drawn by Gries and colleagues is that the CCP responded to the burst in nationalist anger in the $18^{\text {th }}$ September anniversary protests by publicly escalating

\footnotetext{
${ }^{161}$ Toru Horiuchi, "Public Opinion in Japan and the Nationalization of the Senkaku Islands" East Asia no.31 (2014): 23-47

162 See: Smith (2015), 217

163 Weiss (2014)

164 “Anti-Japan protests mark China anniversary”. BBC Online, September 18, 2010

165 Alistair Iain Johnston, "How new and assertive is China's new assertiveness?" International Security, 37, no.4 (2013): 22; Gries, Steiger, and Wang (2015)

166 Cairns and Carlson (2016): 34
} 
its diplomatic and military behavior around the East China Sea ${ }^{167}$. Others have argued that Beijing chose to allow online nationalist sentiment and protests at these times in part to gain bargaining leverage in the dispute ${ }^{168}$. Whichever of these views is true, I argue that while the anniversary landings and protests may have come to pass in any case on another day, the sensitive anniversaries helped to shape when they did occur, and made it more difficult for the regime to crack down when they did. And while even these tensions did not end up sparking a full-scale conflict between the two sides, they meant that the risk of conflict at this time was perhaps as high as it has been in the region in recent years.

\section{Discussion}

It is hard to make the case for the hypothetical scenario that without war anniversaries between Japan and China the disputes discussed would not have occurred in any form. The Japanese government would still have purchased the Diaoyu/Senkaku islands and the Chinese government would still have reacted. However this case does show that nationalist pressures around national anniversaries have shaped how these disputes have played out, particularly over the Yasukuni shrine and Senkaku/Diaoyu islands, by providing opportunities and risks to decision-makers on either side.

Domestic nationalist groups and citizens in both countries have pushed for memorializing activity or public protests, which Chinese leaders have at times undoubtedly chosen to use to bolster their existing foreign policy choices. However at other times both Chinese and Japanese leaders have found themselves giving in to domestic pressures. At the very least the anniversaries have given leaders a choice of

${ }^{167}$ Gries, Steiger, and Wang (2015)

${ }^{168}$ Cairns and Carlson (2016); Weiss (2014) 
how to respond. While these pressures have not led to an outright conflict (even in 2012), they have influenced bilateral tensions, even at times when those tensions have negatively affected the countries' international priorities. This case also supports the theory against two alternative arguments. Even somber anniversaries have sparked nationalist action, while the increase in tensions has had little to do with a greater likelihood of internal conflict. China's response to the Yasukuni Shrine visits also demonstrates how confrontational actions from a rival state on a national day may provoke an even more intense reaction when that national day also celebrates past conflict between the two states. On the other hand, the case does not give evidence for my supplementary hypotheses, $\mathrm{H} 2$ and $\mathrm{H} 3$. In the Yasukuni case, it was the hostile Chinese reaction to anniversary visits that affected bilateral ties, while both China and Japan have taken actions to revise the status quo following anniversaries.

\section{Conclusion}

In this paper I examine whether increases in nationalism have an impact on conflict between states, using national days as a proxy. I have argued that states respond to public pressures that arise from the increased salience of the nation on national days. They may choose to give in to or even encourage these pressures, but on average there is a greater likelihood of conflict. And cross-national evidence shows that in the two months following a national day, states show a significant and sizeable increase in their number of interstate conflicts, particularly for those that initiate the conflict or take a revisionist stance. The confrontations around war anniversaries between China and Japan demonstrate that this effect is particularly strong when the current geopolitical rival is also the target of the national day, and while states do try and 
manipulate the nationalism that arises at this time, they are also subject to its pressures, which may spark unwanted tensions.

This project provides evidence that spikes in the salience of the nation do shape patterns of conflict between nations. Can this tell us anything however about the link between nationalism and conflict more broadly, or does it only apply to national days? Examining the 'regular' occurrence of national days shines light on how any kinds of increases in public nationalism matter throughout the year, whether through annual festivals, unpredictable incidents or in the build up to a conflict. At these times nationalist activists respond to changes in the public sentiment and press for policies that in turn force a choice on decision makers and on average lead to a greater use of force. At the same time leaders can take advantage of these spikes in nationalism to take a more confrontational stance in international relations. This argument does not just apply to time - we might expect public nationalism to also spike in relation to issues or places closely linked to the nation, increasing pressures on decision-makers and giving greater opportunity for confrontational action over these issues ${ }^{169}$.

This paper extends the finding from civil conflict that some periods in the year are more dangerous than others ${ }^{170}$ to international relations. In the periods following national days and anniversaries of conflicts, policymakers should be especially wary of the risk of making provocative moves or pressing territorial claims on international adversaries. For countries like China, initiating new official anniversaries to commemorate past conflicts has its own risks. Such days may help promote domestic

\footnotetext{
${ }^{169}$ With thanks to an anonymous reviewer for noting this extension

${ }^{170}$ Hassner (2011)
} 
legitimacy and provide a certain amount of bargaining leverage in times of tense SinoJapanese relations. They may also make conflict more likely. 